\title{
Intervention Based on Integration of Health Literacy and Health Outcomes in Hypertension "A Systematic Review"
}

\author{
Samsiana Darwis ${ }^{1,2 *} \mathbb{D}$, Syamsiar Siang Russeng ${ }^{3}$, Ridwan Amiruddin ${ }^{2}$ \\ ${ }^{1}$ Faculty of Health Sciences, Universitas Cokroaminoto Makassar, Makassar, Indonesia; ${ }^{2}$ Department of Epidemiology, Faculty \\ of Public Health, Hasanuddin University, Makassar, Indonesia; ${ }^{3}$ Department of Occupational Health and Safety, Faculty of \\ Public Health, Hasanuddin University, Makassar, Indonesia
}

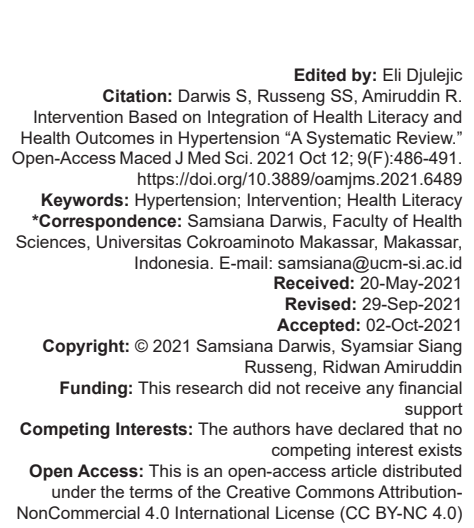

Introduction

Hypertension is a major risk factor for cardiovascular disease and a cause of premature death globally [1]. The prevalence of hypertension is projected to increase to $29.2 \%$ in 2025 [2]. The direct medical costs of treating hypertension in the world are estimated at $\$ 370$ billion per year [3], [4].

There are many interventions have been carried out to control the increasing prevalence of hypertension, either directly given to individuals and the community or through health workers [5]. Nevertheless, the incidence of hypertension is still high, the World Health Organization (WHO) data in 2019 show that the number of adults with hypertension is 1.13 billion [6].

One of the risk factors of hypertension is the low health literacy $(\mathrm{HL})$ of the society [7]. $\mathrm{HL}$ is a combination of various skills and competencies that people need to find, understand, evaluate, use health information and concepts to make choices, reduce health risks, and improve quality of life [8]. Hypertensive patients with low $\mathrm{HL}$ are likely to rarely visit health services resulting in a condition in which they are more likely to be admitted to the hospital compared to those who have adequate health literacy [9].

Hypertension can be controlled by changing lifestyles through good self-management, therefore, people with hypertension must have health literacy skills to support a healthy lifestyle [7]. HL that supports a healthy lifestyle is through health education. Health education is an effective measure to reduce the prevalence and increase the rate of hypertension control [10]. Health education in this case is a population based, eating habit modification, and lifestyle [11].

The previous studies on hypertension related to health literacy have been carried out but predominantly using an observational design resulting in a less than ideal proof if adequate HL will have a positive impact on reducing the prevalence of hypertension [12], [13].

Other studies related to hypertension control have also been carried out with various interventions, but not all of the interventions carried out are integrated with $\mathrm{HL}$ resulting in hypertension being a global problem. Therefore, this literature review aims to identify interventions integrated with $\mathrm{HL}$ and health outcomes for people with hypertension. 


\section{Methods}

The systematic review process follows the 2015 PRISMA/Preferred Reporting Items for Systematic Review and Meta-Analysis Guideline. To identify interventions that are integrated with health literacy and health outcomes for people with hypertension, we look for references using articles published in the past 10 years 2011-2021, which are available on ProQuest, ScienceDirect, PubMed, and Google Scholar. Based on the keyword search, 25,264 articles were found for the $1^{\text {st }}$ time, Google Scholar $(18,000)$, ProQuest (3823), ScienceDirect (3257), and PubMed (184). These articles were then imported to the Mendeley library. The search uses three main keywords, namely, "hypertension, intervention, and health literacy." We use the terms MeSH, "hypertension" or "high blood pressure" or "HTN." We use the terms "intervention" or "integrated program" or "community based" or "RCT." We use the term "health literacy" or "education level."

\section{Inclusion and exclusion criteria}

The inclusion criteria in this review are as follows: (1) A sample of hypertensive patients, (2) a sample in the intervention group received an integrated health education intervention with health literacy, (3) an experimental design (RCT/quasi-experiment), (4) English articles and full text, and (5) open access. The exclusion criteria were as follows: (1) Conference proceedings, (2) study protocol, (3) systematic review/ review of literature, (4) sample of intervention group received intervention but not integrated with health literacy, and (5) qualitative study.

\section{Data extraction}

The study selection process follows the Data Extraction Based on PRISMA 2015 Guidelines in Figure 1 [14]

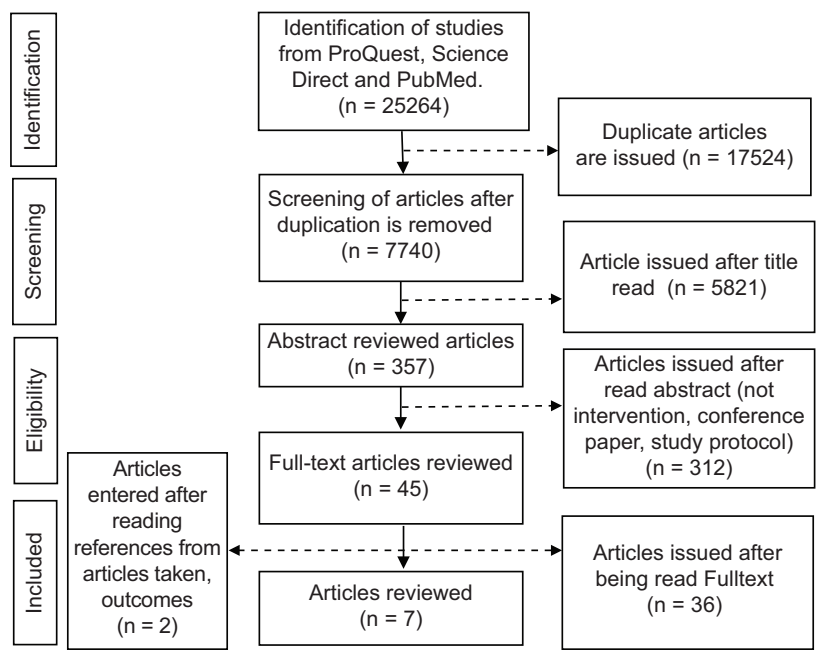

Figure 1: Flowchart literature

\section{Quality assessment}

The Strengthening the Reporting of Observational Studies in Epidemiology (STROBE) checklist was used by reviewers to assess article quality [15]. There are 22 assessment items in the STROBE but in this study, only eight criteria were used, including sample size criteria, sampling methodology criteria, control analysis, response rate, outcome measure, study boundaries, ethical considerations, and control for confounding. Studies that scored $<3$ were considered low quality, 3-6 moderate, and 7-8 as good study quality.

\section{Data analysis}

At this stage, an analysis of the data that have been collected from various articles to be synthesized is carried out. The results of the analysis will answer the research questions that have been set. The division of synthesis items based on the topics arranged consists of three parts, namely, (1) instruments and levels of health literacy, (2) types and duration of intervention, and (3) study outcomes.

\section{Results and Discussion}

\section{Health literacy and hypertension}

Various studies have examined the relationship of $\mathrm{HL}$ with the incidence of hypertension related to blood pressure control, medication adherence, and self-management of patients with hypertension. Low $\mathrm{HL}$ is independently associated with increased blood pressure [16]. It is very important for health-care professionals to understand the patient's $\mathrm{HL}$ before providing intervention or education. Interventions are needed to improve outcomes related to HL [17]. Therefore, it is important to identify people with hypertension at various levels of $\mathrm{HL}$ and provide adequate interventions according to their level of health literacy [7].

There are several instruments used to measure literacy in the selected studies and are shown in Table 1. The instruments include the measurement of $\mathrm{HL}$ in the community and clinical setting which aims to assess the ability to read health terms [18], [19], assess the ability to understand health information [20], [21], [22], [23], and assess the ability to communicate skills [23].

The selection of the right $\mathrm{HL}$ measurement tool is very important because different HL measures and different data collection strategies will be required in certain situations [24]. In this review, there is one study that discusses the effectiveness of the health literacy measurement tools used, namely, research 
Table 1: Instruments and levels of health literacy

\begin{tabular}{|c|c|c|c|c|}
\hline Author/year & Subject/sample & Age & $\begin{array}{l}\text { Instrument of } \\
\text { health literacy }\end{array}$ & $\begin{array}{l}\text { Level of health } \\
\text { literacy }\end{array}$ \\
\hline $\begin{array}{l}\text { Ryvicker } \\
\text { et al., } 2013\end{array}$ & $\begin{array}{l}139 \text { hypertensive } \\
\text { patients }\end{array}$ & $\begin{array}{l}\text { Average age }= \\
48 \text { years }\end{array}$ & $\begin{array}{l}\text { Instrument } \\
\text { used was not } \\
\text { explained }\end{array}$ & Good literacy rate \\
\hline $\begin{array}{l}\text { Kim et al., } \\
2014\end{array}$ & $\begin{array}{l}369 \text { patients with } \\
\text { hypertension }\end{array}$ & $65.6-76.2$ years & HBP-HLS & $\begin{array}{l}\text { Functional } \\
\text { literacy }\end{array}$ \\
\hline $\begin{array}{l}\text { Bokhour, } \\
\text { Barbara et al., } \\
2016\end{array}$ & $\begin{array}{l}618 \text { hypertension } \\
\text { patients }\end{array}$ & Aged $\geq 50$ years & $\begin{array}{l}\text { Short test of } \\
\text { functional } \\
\text { health literacy }\end{array}$ & $\begin{array}{l}\text { Functional } \\
\text { literacy }\end{array}$ \\
\hline $\begin{array}{l}\text { Visanuyothin } \\
\text { et al., } 2018\end{array}$ & $\begin{array}{l}134 \text { hypertensive } \\
\text { patients }\end{array}$ & $\begin{array}{l}\text { Aged } \\
30-70 \text { years }\end{array}$ & HSRI & $\begin{array}{l}\text { Functional, } \\
\text { communicator, } \\
\text { and critical } \\
\text { literacy }\end{array}$ \\
\hline $\begin{array}{l}\text { Delavar et al., } \\
2020 .\end{array}$ & $\begin{array}{l}118 \text { hypertensive } \\
\text { patients }\end{array}$ & $\begin{array}{l}\text { Average age } \\
64 \text { years }\end{array}$ & HELIA & $\begin{array}{l}\text { Functional } \\
\text { literacy }\end{array}$ \\
\hline $\begin{array}{l}\text { Tavakoly Sany } \\
\text { et al., } 2020\end{array}$ & $\begin{array}{l}240 \text { hypertensive } \\
\text { patients and } 35 \\
\text { doctors }\end{array}$ & $\begin{array}{l}\text { Hypertensive } \\
\text { patient age } \geq \\
\text { hypertensive } \\
\text { Physician age = } \\
26-51 \text { years }\end{array}$ & $\begin{array}{l}\text { TOHFLA and } \\
\text { REALM for } \\
\text { hypertensive } \\
\text { patients } \\
\text { HLAQs for } \\
\text { physician }\end{array}$ & $\begin{array}{l}\text { Functional } \\
\text { literacy }\end{array}$ \\
\hline $\begin{array}{l}\text { Wehkamp } \\
\text { et al., } 2021\end{array}$ & $\begin{array}{l}124 \text { hypertensive } \\
\text { patients }\end{array}$ & $\begin{array}{l}\text { Average age }= \\
53 \text { years }\end{array}$ & HLS-EU-Q47 & $\begin{array}{l}\text { General health } \\
\text { literacy }\end{array}$ \\
\hline
\end{tabular}

on improving $\mathrm{HL}$ specifically in digital-assisted decision-making using the European Survey for Health Literacy (HLS-EU-Q47) questionnaire, comprehensive to measure health literacy; access, understand, assess/ process, and apply health-relevant information [21].

The dimensions of $\mathrm{HL}$ have been categorized by several experts including Nutbeam classified $\mathrm{HL}$ into three categories, namely, functional health literacy, communicative $\mathrm{HL}$, and critical $\mathrm{HL}$ [25]. All studies measure $\mathrm{HL}$, but only five studies categorize them into functional, communicative, and critical [18], [19], [20], [22], [23]. Ryvicker et al. measured $\mathrm{HL}$ but not explain the measuring instrument used and neglected to categorize it, the majority $(85.6 \%)$ of the subjects had an adequate level of HL [26]. One study measured specific HL skills after receiving an online information presentation intervention to aid medical decision making [21].

Research subjects are patients with primary hypertension whose blood pressure is not controlled with an average age of 50 years [18], [19], [20], [21], [22]. Only one study examined hypertensive patients aged 18 years [23]. Hypertension is a very common condition experienced by the community and its prevalence is increasing in older adults [27].

\section{Type and duration of intervention}

The types and duration of interventions in this systematic review are shown in Table 2. There are several types of interventions provided; webbased interventions, training-based interventions, health education-based interventions, one-component interventions (DVD aids), and multicomponent interventions including training sessions, workshops, counseling, and health education.
Table 2: Types and duration of intervention

\begin{tabular}{lllll}
\hline Intervention & Design & Follow-up & Quality & References \\
\hline Multicomponent program & $\begin{array}{l}\text { Randomized } \\
\text { clinical control } \\
\text { trial }\end{array}$ & 12 months & 8 & {$[19]$} \\
$\begin{array}{l}\text { Electronic-based health } \\
\text { education }\end{array}$ & $\begin{array}{l}\text { Randomized } \\
\text { controlled trial } \\
\text { (RCT) }\end{array}$ & 6 months & 7 & {$[27]$} \\
$\begin{array}{l}\text { Behavioral change support } \\
\text { apparatus }\end{array}$ & $\begin{array}{l}\text { Randomized } \\
\text { clinical trial } \\
\text { Multicomponent program }\end{array}$ & 6 months & 7 & {$[20]$} \\
$\begin{array}{l}\text { Quasi- } \\
\text { experimental }\end{array}$ & 3 months & 7 & {$[21]$} \\
$\begin{array}{l}\text { Multicomponent program } \\
\text { RCT }\end{array}$ & $\begin{array}{l}1 \text { month } \\
\text { Web-based months } \\
\text { RCT }\end{array}$ & 8 & {$[23]$} \\
& RCT & $\begin{array}{l}\text { Assessment } \\
\text { on the next } \\
\text { consultation visit }\end{array}$ & 7 & {$[24]$} \\
\hline & & & \\
\hline
\end{tabular}

multicomponent [18], [20], [22]. One study fully describes the interventions carried out, namely, 6 weekly educational sessions on developing hypertension management skills, including $\mathrm{HL}$ training followed by telephone counseling and home blood pressure (BP) monitoring for 12 months [18]. Web-based interventions with evidence-based patient decision aids (EbPDAs) improve the health literacy of hypertensive patients to make the right medical decisions regarding their health [21].

Health education-based interventions are basically carried out by all researchers but with different approaches. The integrated program with blood pressure monitoring at home and village health volunteers is plausible to be implemented well because it is supported by health education about selfmanagement of hypertension [20]. Self-management education adapted to health literacy was shown to increase medication adherence $(p<0.05)$ although it was not significant in lowering BP $(p>0.05)$. Electronicbased health education is suitable to be applied to patients from the emergency department who are often not aware of suffering from hypertension, they need regular monitoring to control their blood pressure and other clinical effects [21].

Health education can result in lifestyle modification and increase adherence to antihypertensive drugs to improve effective BP control in hypertensive patients [11]. Interactive education workshops may be the most effective strategy in a community-based health promotion education program for hypertensive patients in increasing patient knowledge about hypertension and reducing clinical risk factors to prevent hypertensionrelated complications [28].

The timing of the intervention follow-up affected the final outcome of each study. The average length of intervention was 6 months. Overall, patients who completed the 6-month study protocol achieved a significant reduction in systolic blood pressure from baseline to 180 days of follow-up $(159 \mathrm{mmHg}$ vs. $131 \mathrm{mmHg} ; \mathrm{p}<0.001)$, although the difference in reduction between the two groups was not statistically significant [26]. HL scores showed no difference 
between the two groups at 6 months, but there were significant differences in print and functional $\mathrm{HL}$ scores at 12 and 18 months after the intervention; scores for the intervention group were much higher [18]. Intervention and a short follow-up period, for example, 1 month may be factors that influence the insignificant change in post-test systolic and diastolic blood pressure in the intervention group [22].

All reviewed studies used an experimental design. There is one study that uses a quasiexperimental design, where the research sample is given the choice to be involved in the intervention program [20]. The other six studies used a randomized controlled trial design [18], [19], [21], [22], [23], [26]. A review of the literature on the quality of randomized controlled trials in health literacy described areas of experimental design strength in good randomization and allocation concealment [29].

\section{Study outcomes}

The literature review on outcome studies is shown in Table 3. Outcomestudies in seven studies can be categorized; medical outcomes health (reducing systolic and diastolic blood pressure, lowering body mass index BMI) [18], [20], health literacy skills [18], [21], [23], and hypertension self-management behavioral [intentions, knowledge, blood pressure control, and medication adherence]) [18], [19], [20], [21], [22], [23], [26].

Table 3: Study outcomes

\begin{tabular}{|c|c|c|}
\hline Aims & Study outcomes & References \\
\hline Testing intervention effect & Significant & [18] \\
\hline $\begin{array}{l}\text { Researching efficacy and education moderator } \\
\text { intervention }\end{array}$ & Non-significant & [26] \\
\hline Grading the effect of hypertension effect to intention & Significant & [19] \\
\hline Knowing the effectivity of an integrated program & Significant & [20] \\
\hline Evaluating the effect of self-management education & Significant & [22] \\
\hline $\begin{array}{l}\text { Understanding the effectivity of communication skills } \\
\text { training on the outcome of hypertension }\end{array}$ & Significant & [23] \\
\hline $\begin{array}{l}\text { Understanding the effect of evidence-based patient } \\
\text { decision aids (EBPDAs) }\end{array}$ & Significant & [21] \\
\hline
\end{tabular}

The seven articles that have been reviewed, only one article shows that the outcome study results from the interventions that have been carried out in the study are not significant, even though the level of BP control that has been used is not significant. This high level was achievable overall because the study aim was to examine the efficacy and moderator of an educational intervention in an RCT on BP control at 180 days postintervention [26]. While the outcome study showed significant results [18], [19], [20], [21], [22], [23], the intervention objectives were said to have been achieved.

Various intervention objectives have been discussed in the study, such as a study on the effect of community-based self-help multimodal behavioral intervention in the elderly which aims to examine the effect of the intervention on (i) high blood pressure (HBP) management as the main outcome and (ii) health literacy, self-efficacy, medication adherence, and psychological status. (depression) as a secondary outcome [18].
Studies on the effect of interventions are also discussed by a study conducted on the elderly in Iran with the aim of knowing the effect of digital evidence-based patient decision aids (EbPDAs) for hypertension on $\mathrm{HL}$ [21] not only the effect of intervention but other studies also discuss the effectiveness of the intervention [20], [23], such as in this study aims to determine the effectiveness of an integrated program with home blood pressure monitoring (HBPM) and village health volunteers (VHVs) in supporting the target population [20] and to gauge the effectiveness of physician communication skills training on hypertension outcomes and HL skills, self-efficacy, and medication adherence in patients with uncontrolled BP [23]. To affirm the impact and evaluate the effect of the intervention, the objectives of the study on African-American patients were to evaluate the effect of self-management education tailored to health literacy on medication adherence and blood pressure control [19] and to evaluate the effect of self-management education tailored to health literacy on medication adherence and BP control [22].

Based on the literature study, from the six studies, the aims are seen effectiveness, effect, and impact of interventions that produce significant outcome studies.

The effect of the intervention was significant in improving hypertension control by taking medication, significantly reducing systolic and diastolic BP, increasing $\mathrm{HL}$ scores, indicators of self-efficacy, and knowledge about hypertension [18]. Another effect, the intervention significantly increased the ability of specific $\mathrm{HL}$ about hypertension [21]. The effectiveness of the intervention succeeded in significantly lowering BP and BMI, and increasing knowledge and self-management behavior among urban patients with uncontrolled BP [20] and significantly effective in changing physician communication skills, patient's health literacy, medication adherence, and self-efficacy [23]. The efficacy of systolic and diastolic blood pressure of patients also significantly increased adherence to hypertension treatment but was not effective on blood pressure control behavior, decreased diastolic and systole blood pressure in the intervention group but the difference with the control group was not significant [22]. To assess the impact of the intervention in the outcome study, it showed that the results were significantly more likely to have a much greater intention to carry out healthy lifestyle behaviors in controlling hypertension [19].

\section{Conclusion}

Interventions that are integrated with health literacy by considering the health literacy abilities of hypertensive patients will improve the health outcomes of hypertensive patients in medical outcomes health, 
health literacy skills, and hypertension self-management behavioral.

\section{References}

1. Ozoemena EL, Iweama CN, Agbaje OS, Umoke PC, Ene OC, Ofili PC, et al. Effects of a health education intervention on hypertension-related knowledge, prevention and self-care practices in Nigerian retirees: A quasi-experimental study. Arch Public Health. 2019;77(1):23. https://doi.org/10.1186/ s13690-019-0349-x

PMid:31143446

2. Abegaz TM, Shehab A, Gebreyohannes EA, Bhagavathula AS, Elnour AA. Nonadherence to antihypertensive drugs: A systematic review and meta-analysis. Medicine (Baltimore). 2017;96(4):e5641. https://doi.org/10.1097/ md.0000000000005641

PMid:28121920

3. Adane E, Atnafu A, Aschalew AY. The cost of illness of hypertension and associated factors at the university of gondar comprehensive specialized hospital northwest Ethiopia, 2018. Clinicoecon Outcomes Res. 2020;12:133-40. https://doi. org/10.2147/ceor.s234674

PMid:32184636

4. Angell SY, De Cock KM, Frieden TR. A public health approach to global management of hypertension. Lancet. 2015;385(9970):825-7. https://doi.org/10.1016/ s0140-6736(14)62256-x

PMid:25752181

5. Visanuyothin S, Manwong M, Thongnopakun S. Communitybased health literacy program on uncontrolled hypertension in urban area, Thailand. J Public Health Dev. 2020;18(2):74-88.

6. World Health Organization. Hypertension. Geneva: World Health Organization; 2020. Available from: https://www.who.int/news-room/ fact-sheets/detail/hypertension. [Last accessed on 2021 May 17].

7. Du S, Zhou Y, Fu C, Wang Y, Du X, Xie R. Health literacy and health outcomes in hypertension: An integrative review. Int J Nurs Sci. 2018;5(3):301-9. https://doi.org/10.1016/j. ijnss.2018.06.001

PMid:31406840

8. Meherali S, Punjani NS, Mevawala A. Health literacy interventions to improve health outcomes in low-and middleincome countries. Health Lit Res Pract. 2020;4(4):e251-66. https://doi.org/10.3928/24748307-20201118-01

PMid:33313935

9. Gaffari-Fam S, Babazadeh T, Oliaei S, Behboodi L, Daemi A. Adherence to a health literacy and healthy lifestyle with improved blood pressure control in Iran. Patient Prefer Adherence. 2020;14:499-506. https://doi.org/10.2147/ppa.s244820 PMid:32184576

10. Shrivastava SR, Shrivastava PS, Ramasamy J. The determinants and scope of public health interventions to tackle the global problem of hypertension. Int J Prev Med. 2014;5(7):807-12. PMid:25104990

11. Ribeiro AG, Ribeiro SM, Dias $C M$, Ribeiro $A Q$, Castro $F A$, Suárez-Varela MM, et al. Non-pharmacological treatment of hypertension in primary health care: A comparative clinical trial of two education strategies in health and nutrition. BMC Public Health. 2011;11:637. https://doi.org/10.1186/1471-2458-11-637 PMid:21831277

12. Visscher BB, Steunenberg B, Heijmans M, Hofstede JM,
Devillé W, van der Heide I, et al. Evidence on the effectiveness of health literacy interventions in the EU: A systematic review. BMC Public Health. 2018;18(1):1414. https://doi.org/10.1186/ s12889-018-6331-7

PMid:30594180

13. Walters R, Leslie SJ, Polson R, Cusack T, Gorely T. Establishing the efficacy of interventions to improve health literacy and health behaviours: A systematic review. BMC Public Health. 2020;20(1):1040. https://doi.org/10.1186/s12889-020-08991-0 PMid:32605608

14. Moher D, Liberati A, Tetzlaff J, Altman DG, PRISMA Group. Preferred reporting items for systematic reviews and meta-analyses: The PRISMA statement. PLoS Med. 2009;6(7):e1000097. https://doi.org/10.1371/journal. pmed.1000097

PMid:19621072

15. Vandenbroucke JP, von Elm E, Altman DG, Gøtzsche PC, Mulrow CD, Pocock SJ, et al. Strengthening the reporting of observational studies in epidemiology (STROBE): Explanation and elaboration. Int J Surg. 2014;12(12):1500-24. https://doi. org/10.1016/j.ijsu.2014.07.014

PMid:25046751

16. Amir, Weber, Beard, Bomyea T. Association of health literacy with elevated blood pressure: A cohort study of hospitalized patients. Med Care. 2008;23(1):364-53.

PMid:24556896

17. Geboers B, Reijneveld SA, Koot JA, de Winter AF. Moving towards a comprehensive approach for health literacy interventions: The development of a health literacy intervention model. Int J Environ Res Public Health. 2018;15(6):1268. https://doi.org/10.3390/ijerph15061268 PMid:29914065

18. Kim KB, Han HR, Huh B, Nguyen T, Lee H, Kim MT. The effect of a community-based self-help multimodal behavioral intervention in Korean American seniors with high blood pressure. Am J Hypertens. 2014;27(9):1199-208. https://doi.org/10.1093/ajh/ hpu041

PMid:24671049

19. Bokhour BG, Fix GM, Gordon HS, Long JA, DeLaughter K, Orner MB, et al. Can stories influence African-American patients' intentions to change hypertension management behaviors? A randomized control trial. Patient Educ Couns. 2016;99(9):1482-8. https://doi.org/10.1016/j.pec.2016.06.024 PMid:27387121

20. Visanuyothin S, Plianbangchang S, Somrongthong R. An integrated program with home blood-pressure monitoring and village health volunteers for treating poorly controlled hypertension at the primary care level in an urban community of Thailand. Integr Blood Press Control. 2018;11:25-35. https://doi. org/10.2147/ibpc.s160548 PMid:29713195

21. Wehkamp K, Kiefer FB, Geiger F, Scheibler F, Rueffer JU, Donner-Banzhoff $\mathrm{N}$, et al. Enhancing specific health literacy with a digital evidence-based patient decision aid for hypertension: A randomized controlled trial. Patient Prefer Adherence. 2021;15:1269-79. https://doi.org/10.2147/ppa.s311470 PMid:34163144

22. Delavar F, Pashaeypoor S, Negarandeh R. The effects of selfmanagement education tailored to health literacy on medication adherence and blood pressure control among elderly people with primary hypertension: A randomized controlled trial. Patient Educ Couns. 2020;103(2):336-42. https://doi.org/10.1016/j. pec.2019.08.028 PMid:31451361

23. Tavakoly Sany SB, Behzhad F, Ferns G, Peyman N. 
Communication skills training for physicians improves health literacy and medical outcomes among patients with hypertension: A randomized controlled trial. BMC Health Serv Res. 2020;20(1):60. https://doi.org/10.1186/s12913-020-4901-8 PMid:31973765

24. Nguyen $\mathrm{TH}$. The state of the science of health literacy measurement. Physiol Behav. 2018;176(1):139-48.

25. Nutbeam D. Defining, measuring and improving health literacy. Health Eval Promot. 2015;42(4):450-6.

26. Ryvicker M, Feldman PH, Chiu YL, Gerber LM. The role of patient activation in improving blood pressure outcomes in black patients receiving home care. Med Care Res Rev. 2013;70(6):636-52. https://doi.org/10.1177/1077558713495452

\section{PMid:23864112}

27. Alfie J, Cuffaro PE. Hypertension in the elderly. Encycl Biomed Gerontol. 2019;4(5):258-70.

28. Lu CH, Tang ST, Lei $Y X$, Zhang MQ, Lin WQ, Ding SH, et al. Community-based interventions in hypertensive patients: A comparison of three health education strategies. BMC Public Health. 2015;15:33. https://doi.org/10.1186/s12889-015-1401-6 PMid:25631224

29. Brainard J, Wilsher SH, Salter C, Loke YK. Methodological review: Quality of randomized controlled trials in health literacy. BMC Health Serv Res. 2016;16(1):246. https://doi.org/10.1186/ s12913-016-1479-2

PMid:27402048 